ارزيابى صفات بيوشيميايى و انتقال مجدد مواد يرورده جو (Hordeum vulgare L.) در كشت مخلوط تأخيرى با نخود (Cicer arietinum L) در شرايط تنش كم آبى

\author{
نخين محاويه اسعدى' و احسان بيزّزاده ب*

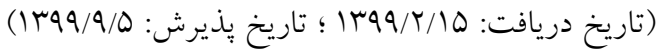

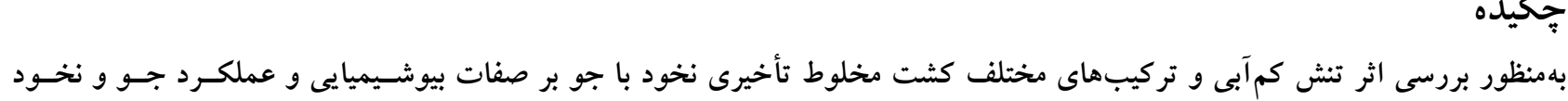

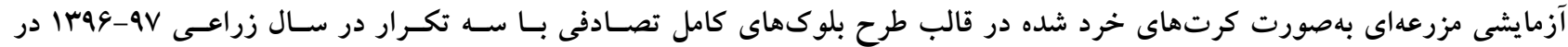

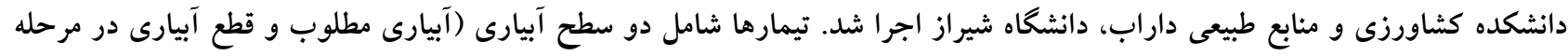

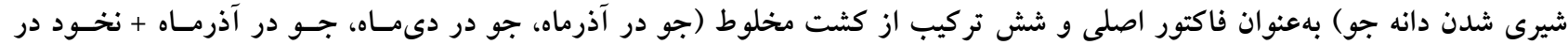

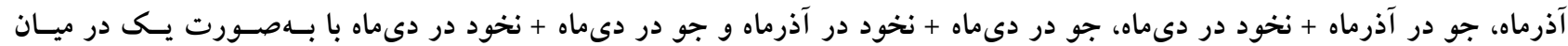

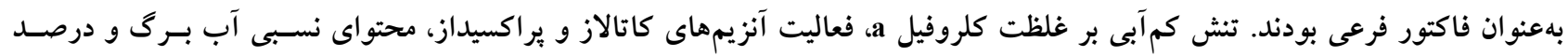

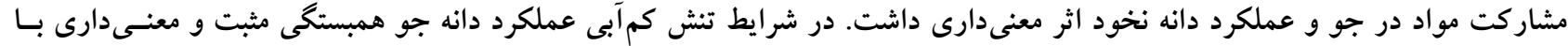
محتواى نسبى آب (R)

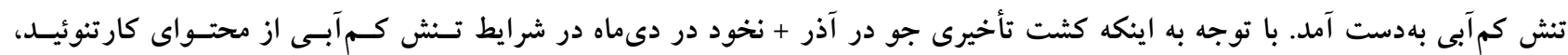

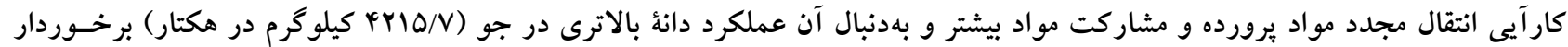

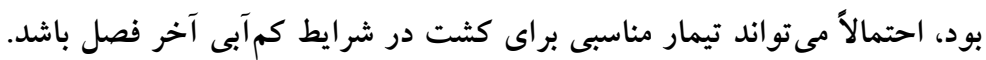

وازههاى كليدى: يراكسيداز، كاتالاز، كاروتنوئيد، كلروفيل a، محتواى نسبى آب

ا و r. بهترتي دانشجوى كارشناسى ارشد و دانشيار، بخش اكرواكولوزى، دانشكده كشاورزى و منابع طبيعى داراب، دانشاه شيراز

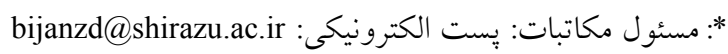


كه از جمله اين عوامل مىتوان به كاهش رنخيزههاى فتوسـتزى

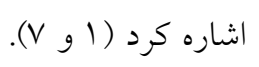

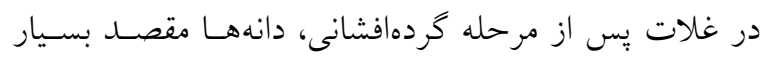

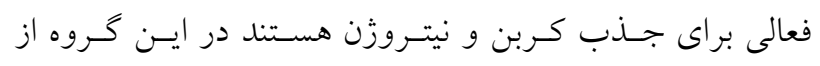

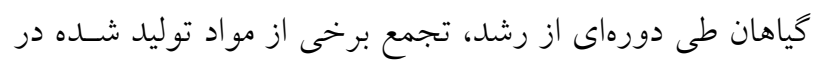

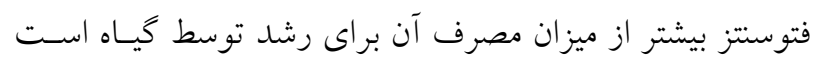

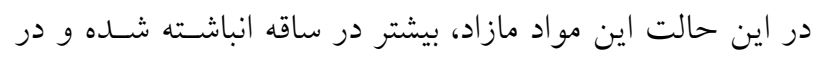

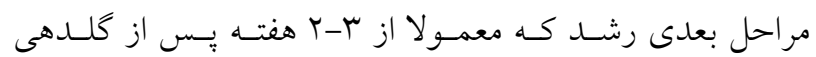

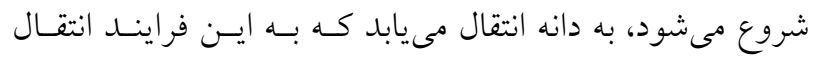

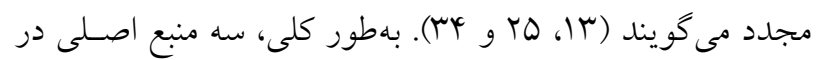

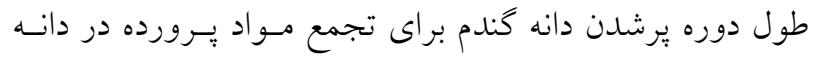

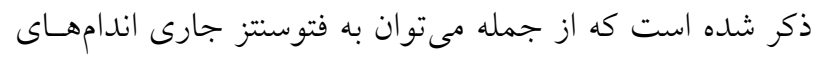
مختلف، انتقال مجلد مواد ذخيره شده در اندامهاى رويشى قبل

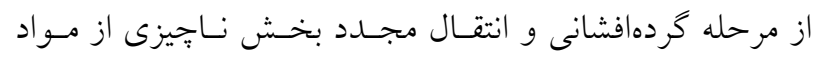

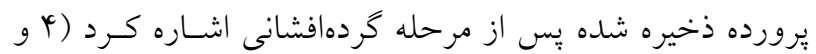

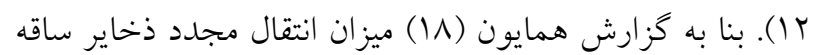
در شرايط تنش بهطور معنى دارى بيشتر از شرايط مساعد است.

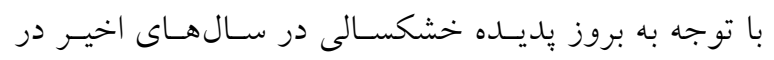

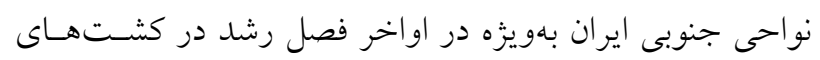

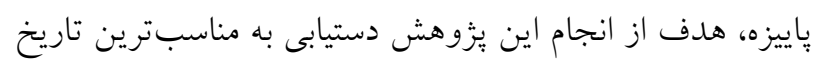
كاشت جو در كشت مخلوط تأخيرى با نخود و بررسى تغييرات

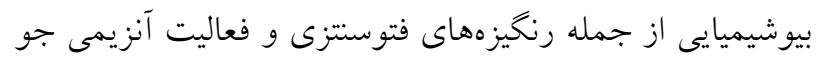

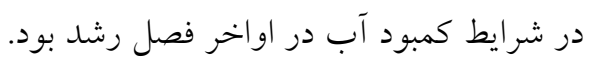

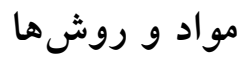
اين آزمايش بهصورت كرتهاى خرد شده (اسـيليت پـاتلات) در

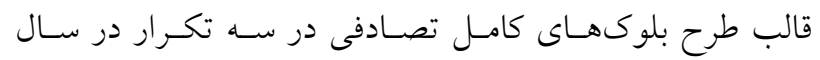

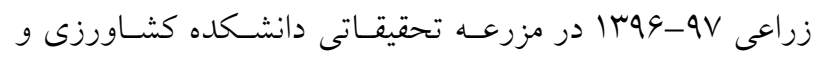

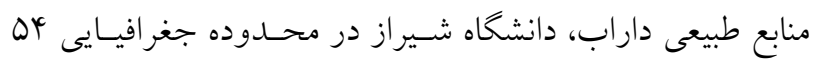

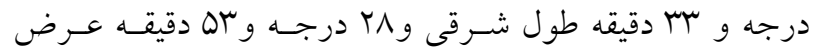

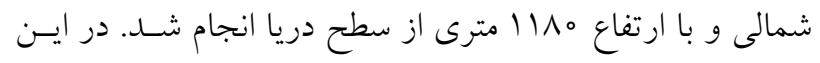

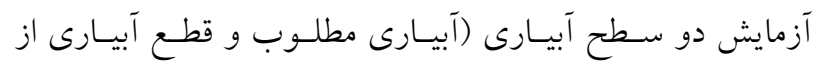

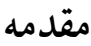

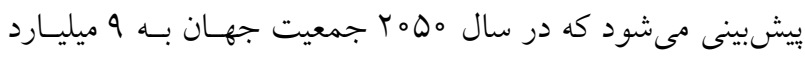

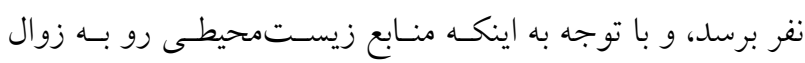

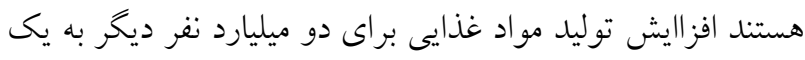

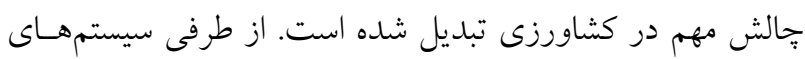

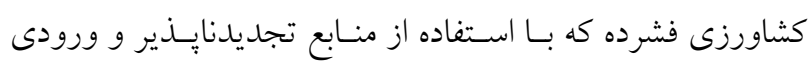

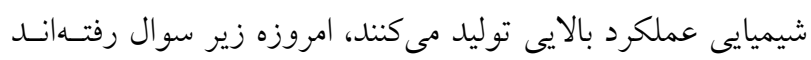

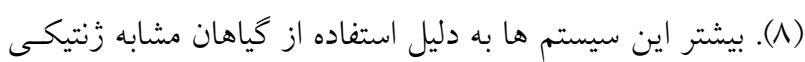

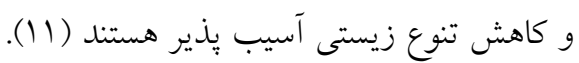

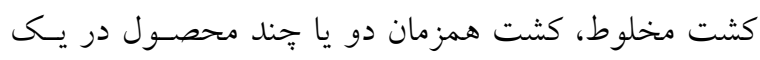

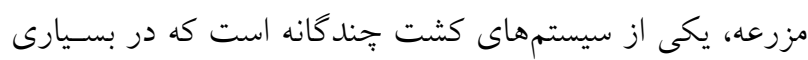

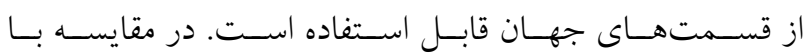

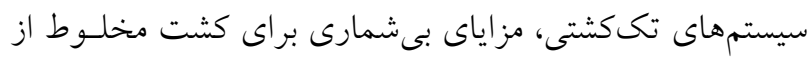

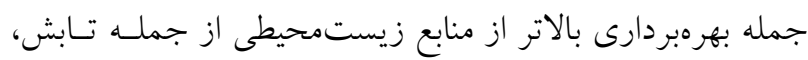

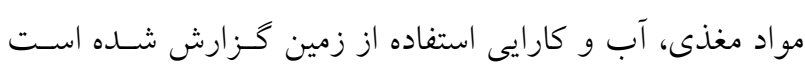

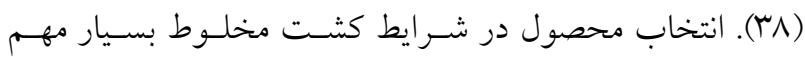
است. در سيتمهـاى كشـت مخلـوط بايســــــهـ محصـولاتى كـهـ مى تواند با حداقل رقابت و حداكثر سود رشد كنند توجه شـود. در ميان سيستمهاى مختلف كشت مخلوط كه بالاترين توليــ را دارا هستند، كشت حبوبات، بهعنوان محصـولات تثبيـت كنتـده

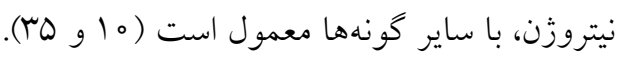

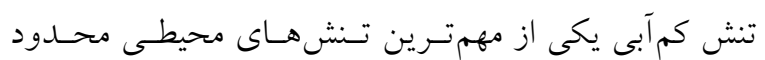

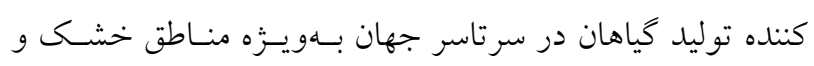

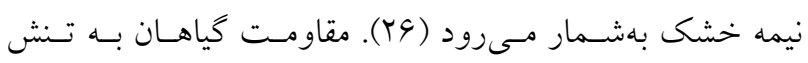

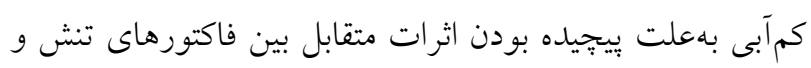

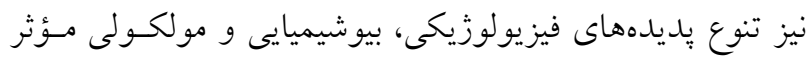

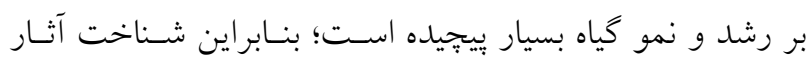

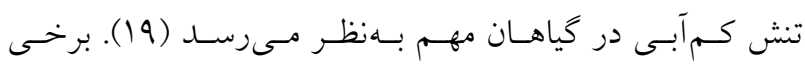

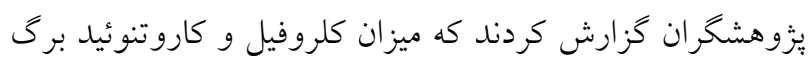

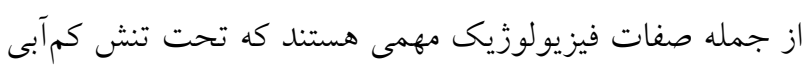

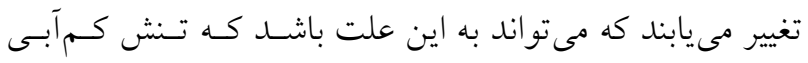
توسط عوامل روزنهاى و غيرروزنهاى فتوسنتز را كاهش مىدهد 
و ابتداى ساقه رفتن كياه جو به كرتها اضافه شد.

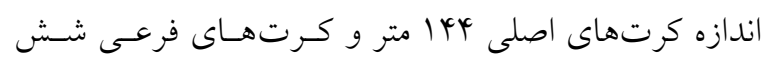

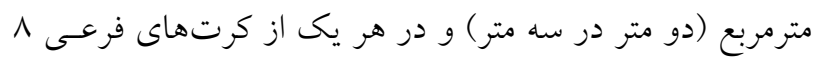

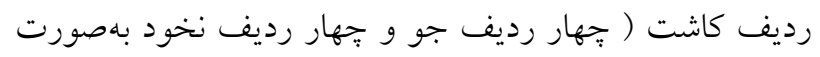

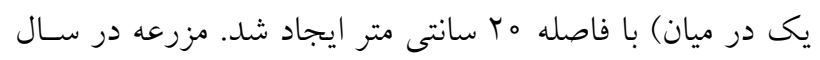

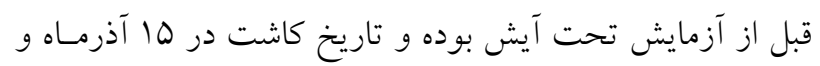

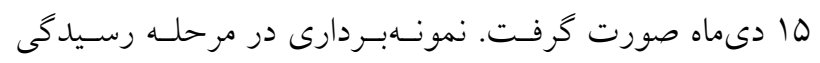

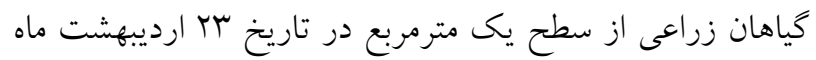

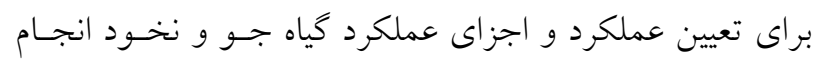

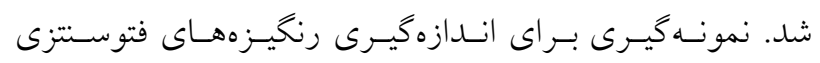

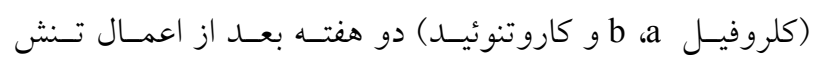

$$
\text { صورت كرفت. }
$$

\section{اندازهيرى رنغيزههاى فتوسنتزى گياه جو}

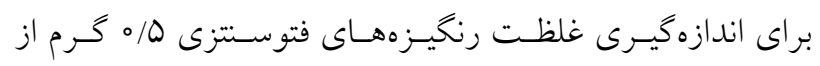

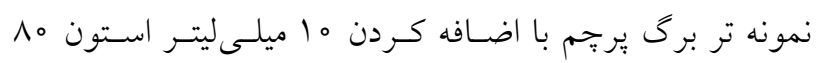

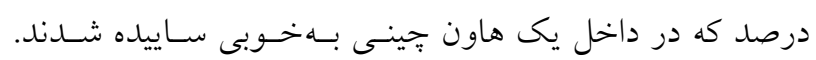

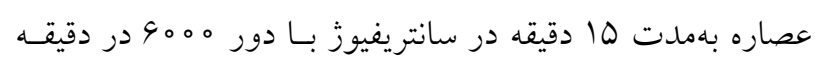

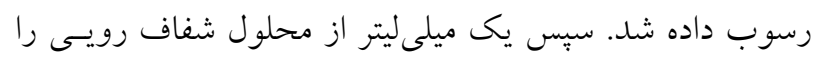

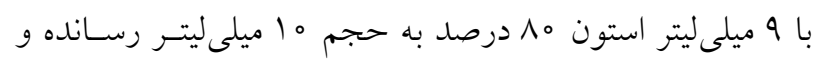

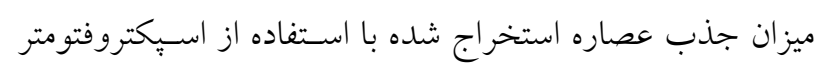

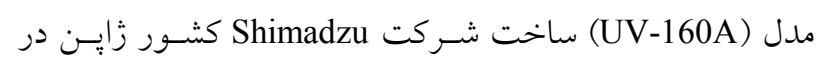

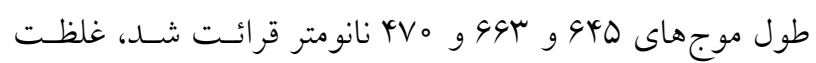
رنخيزههاى فتوسنتى برحسب ميلى گرم بر گرم وزن تر محاسبه

شد (r): (r) (ب)

Chlorophyll $a=(19.3 \times$ A $663-0.86 \times \mathrm{A} 645) \mathrm{V} / 100 \mathrm{~W}$

Chlorophyll $b=(19.3 \times \mathrm{A} 645-3 / 6 \times \mathrm{A} 663) \mathrm{V} / 100 \mathrm{~W}(\mathrm{Y})$

\section{Carotenoid $=$}

$(100 \times \mathrm{A} 470)-(3.27 \times \mathrm{mg}$ chl. $a)-(104 \mathrm{mg}$ chl. $b) / 227$

حجم محلول صاف شده (محلول فوقانى حاصل از سانتريفيوز) =V

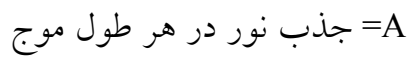

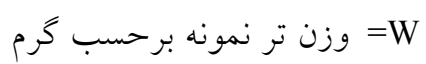

ابتداى شيرى شدن دانه جو) بهعنوان عامل اصلى و شش تيمـار

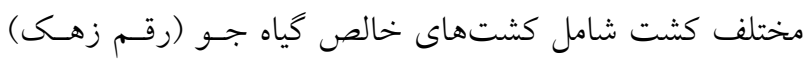
كاشت شده در تاريخهاى كاشت آذرماه و دىماه و تركيبهـاى دهاى مختلف كشت مخلوط تأخيرى شامل: جو آذرماه + نخود آذرماه

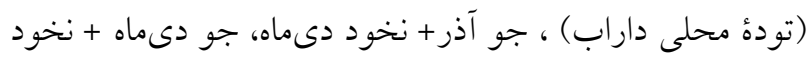

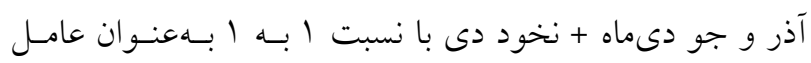

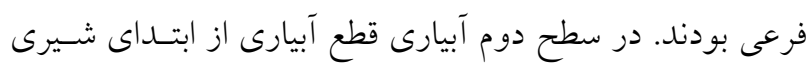

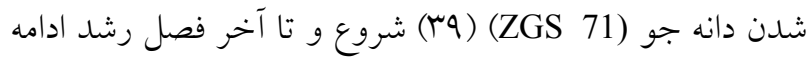

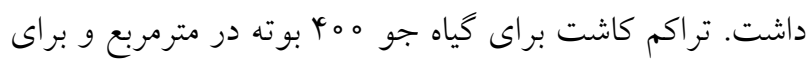

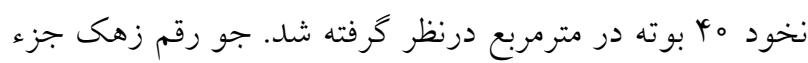

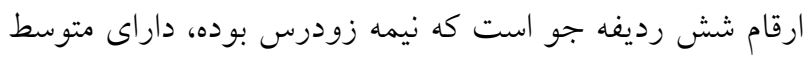

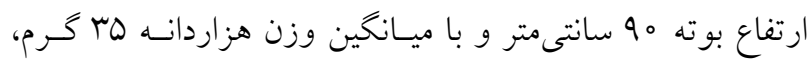

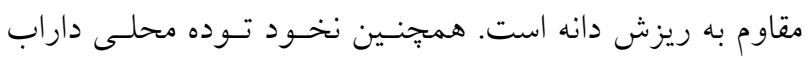

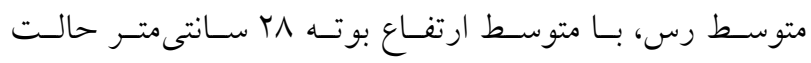

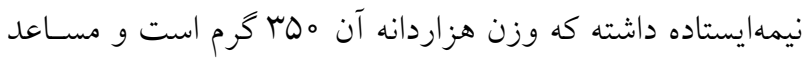
براى نواحى كرم و خشكى اسـت. دادههـاى هواشناسـى منطقـهـ

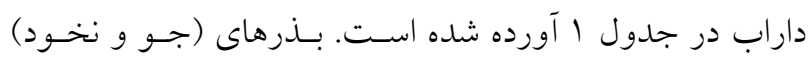
مورد نياز مطالعه از مركز تحقيقات حسن آباد داراب، شيراز تهيه

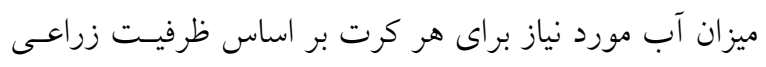

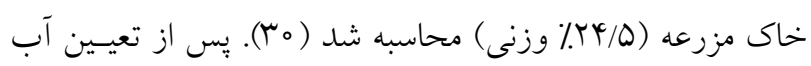

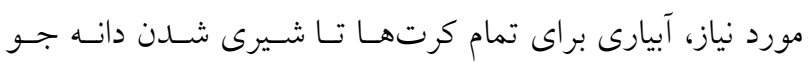

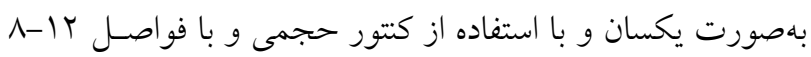

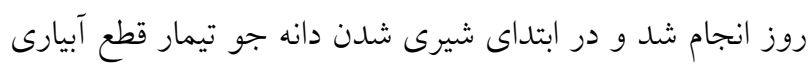

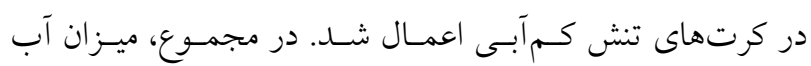

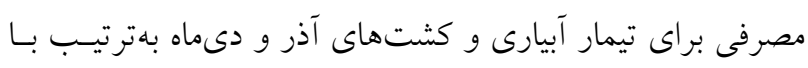

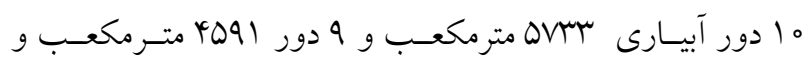
براى تنش خشكى از اوايل شيرى شدن دانه جو براى كشتهـاى

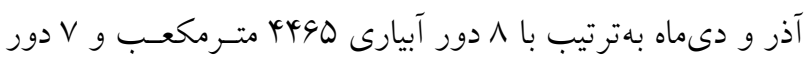

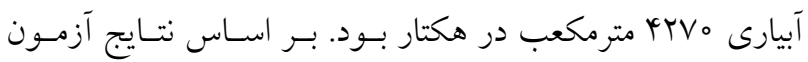

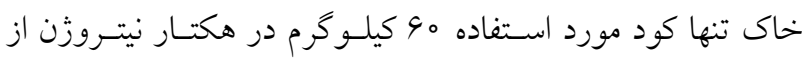

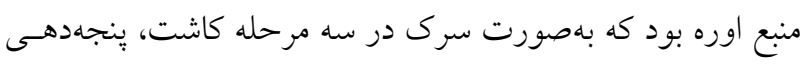




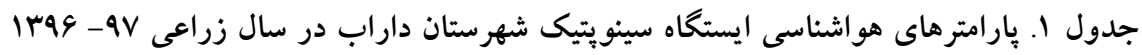

\begin{tabular}{|c|c|c|c|c|c|c|c|c|}
\hline ارديبهشت & فروردين & اسفند & بهمن & دى & آذر & 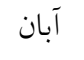 & مهر & ماه \\
\hline $19 / 9$ & $\mid r / 1$ & $1 / 9$ & $4 / 0$ & $r / \mu$ & $Y / V$ & $9 / 0$ & $10 / 9$ & حداقل دما (Co \\
\hline$M T / T$ & TN/G & $T Y / Q$ & $r 1 / K^{c}$ & $r \circ / 1$ & $19 / 0$ & $r V / T^{c}$ & 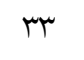 & حداكثر دما (م) \\
\hline$T Y / Q$ & $r \circ / 4$ & $10 / 9$ & $1 T / 9$ & $11 / \mathrm{V}$ & $\mid r / 1$ & $1 N / 0$ & $T Y / D$ & متوسط دما (م) \\
\hline $1 / \mathrm{V}$ & $9 / 4$ & Gr & $\circ / 4$ & $1 / \pi$ & $r G / T$ & $1 / 9$ & $\circ \%$ & بارندكى (mm) \\
\hline
\end{tabular}

ثانيه جذب دوم را مسىخـوانيم)، v = حجم كـل عصـاره بـرى

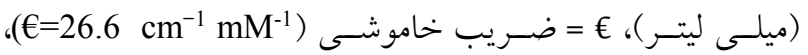
=vs = حجم نمونه برداشت شده (ميلى ليتر)، FW= وزن تر نمونه برى برداشت شده (كرم).

$$
\text { اندازميرى محتواى نسبى آب برى }
$$

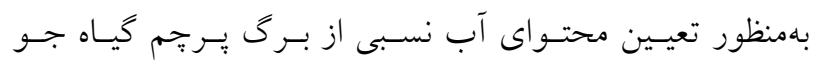

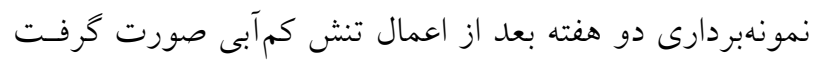

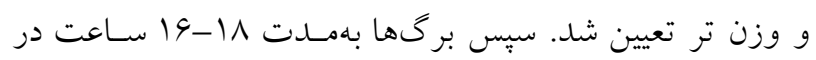

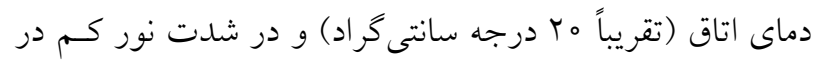

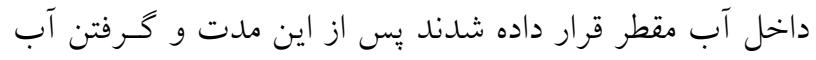

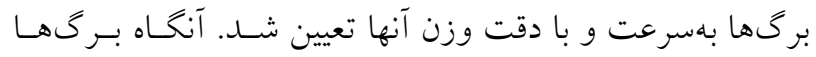

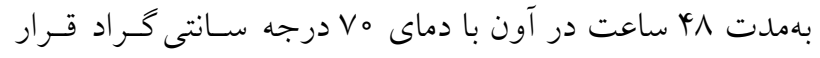

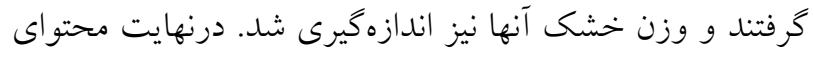

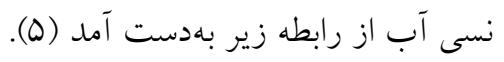

= محتواى آب نسبى برى = من

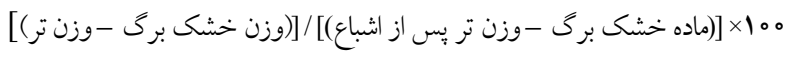

\section{اندازه كيرى انتقال مجدد مواد}

براى محاسـبه انتقـال مجـدد مـاده خشـك، در مرحلـه مه درصــ كلــهى (ZGS 90) و رسـيدگى و فيزيولوزيـك (ZGS 99) )ـــنج بوته بهطور تصادفى از هر كرت كفبر و توزين شده، انـام هـوايى

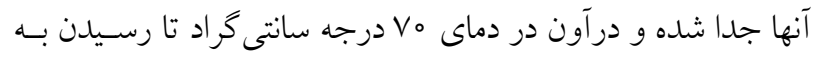
وزن ثابت خشكانده و وزن خشك اندازهگيرى شد (4 (1).

= انتقال مجدد مواد يرورده (كرم در بوته)

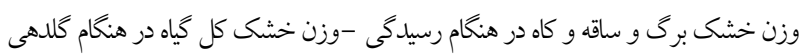

فعاليت آنزيم كاتالاز براى اندازهيرى فعاليت آنزيم كاتالاز ه/ه گرم از نمونه تر برى

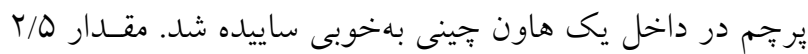

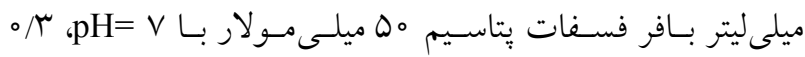

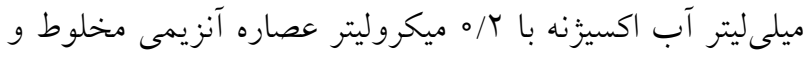

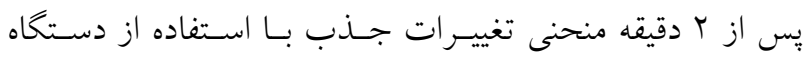

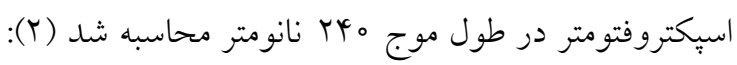

Catalase activity $=\frac{\Delta \times v}{€ \times \mathrm{vs} \times \mathrm{FW}}$

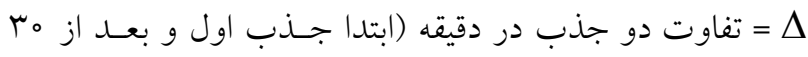

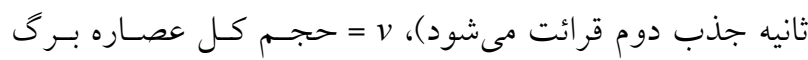

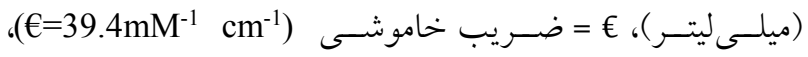
vs برى برداشت شده (كرم)

$$
\text { فعاليت آنزيم بر اكسيداز }
$$

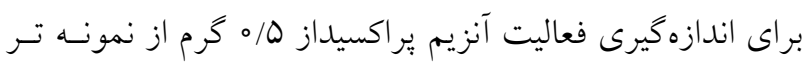

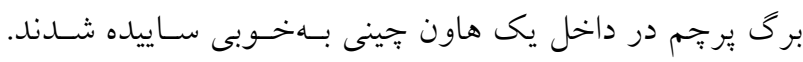

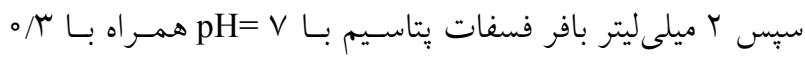

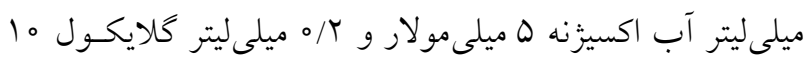

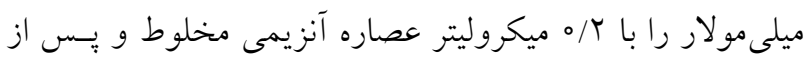

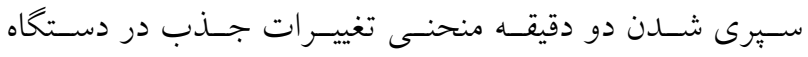

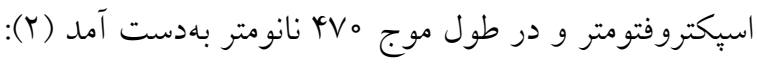
Peroxidase activity $=\frac{\Delta \times v}{€ \times v \mathrm{vs} \times \mathrm{FW}}$

D = تفاوت دو جذب در دقيقه (ابتدا جـــب اول و بعـــ از مب 
در يثزوهشى بيان كردند كه تنش كمآبى اثرى بر محتواى كلروفيـل

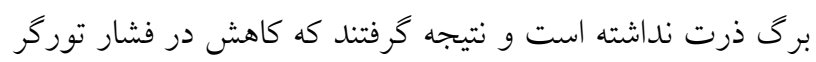

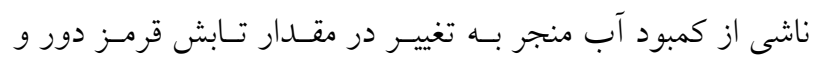

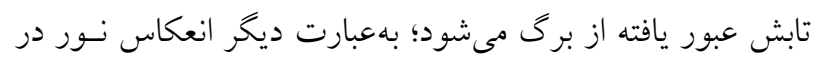
اثر تنش آبى افزايش مىيابد (Iاب).

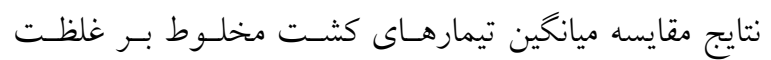

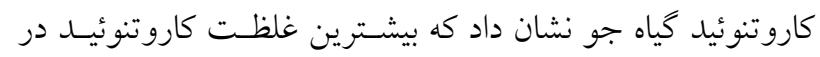

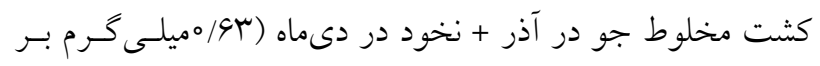

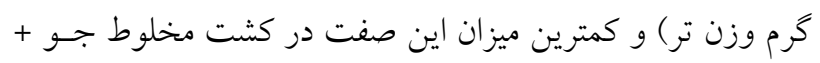

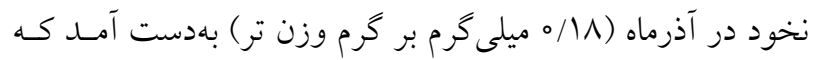

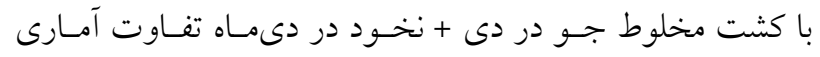
معنى دارى نداشت (شكل ()). نقش اصلى كاروتنوئيدها جلوكيرى

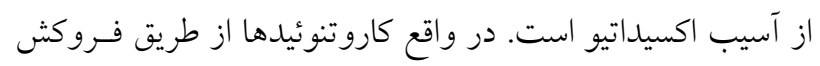

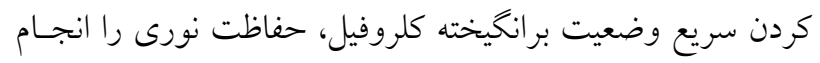

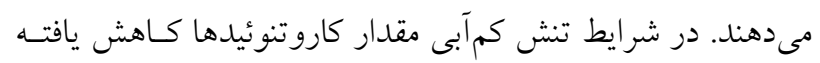

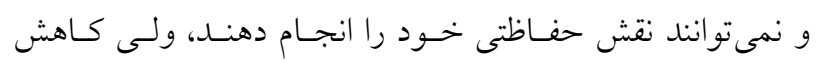

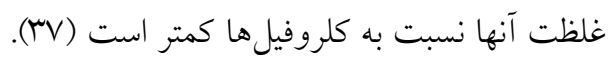

$$
\text { فعاليت آنزيمهاى آنتىاكسيدانى }
$$

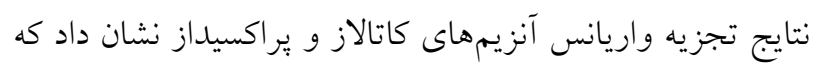

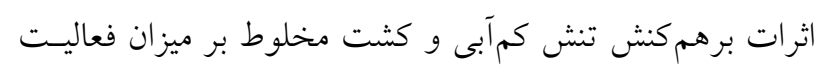

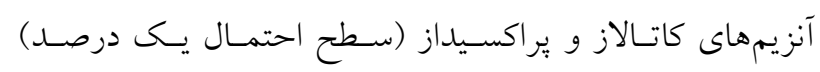

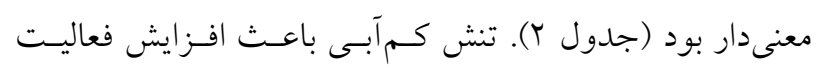

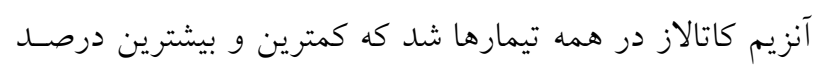

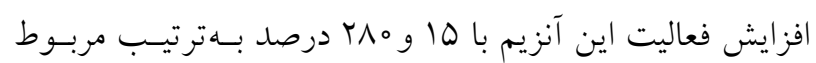

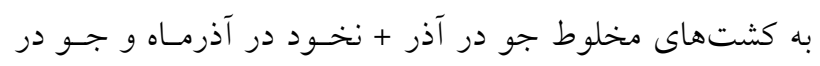

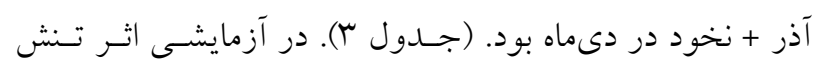

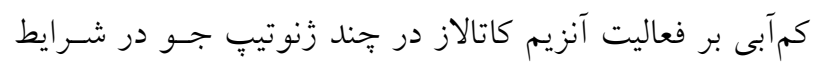

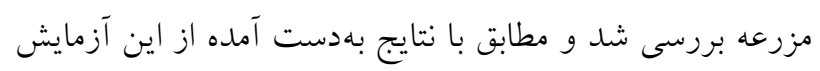

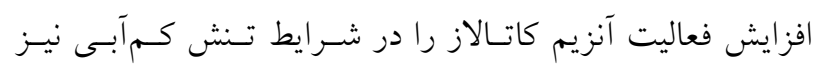

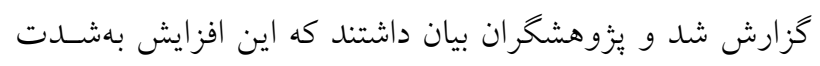
تنش و مرحله وقوع تنش در ارقام مختلف جو بستخى دارد (r).
= درصد كارايى انتقال مجدد مواد يرورده

(وزن خشى كل گياه در هنگام كلدهى / انتقال مجدد مـواد يــرورده) $\times 100$

= درصد مشاركت مواد يروردهه

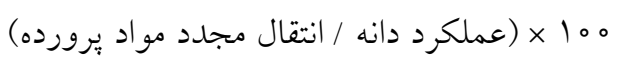

تجزيه و تحليل دادهها با استفاده از نرمافزار آمارى SAS نسـخه

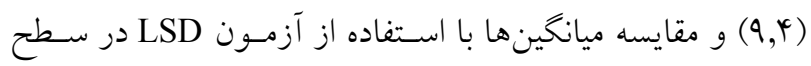
احتمال پينج درصد انجام گرفت.

\section{نتايج و بحث}

\section{محتواى كلروفيل a b a}

اثرات ساده تنش كمآبى، كشت مخلوط و برهم كنش تنش كم آبسى

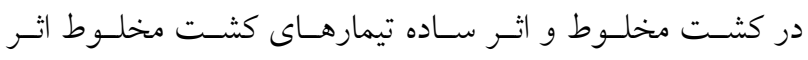

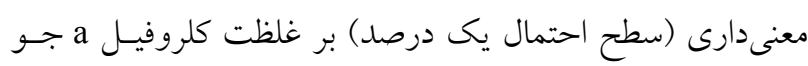

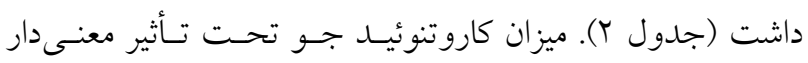
(سطح احتمال يك درصد) تيمار كشت مخلوط قرار كرفت. نتايج

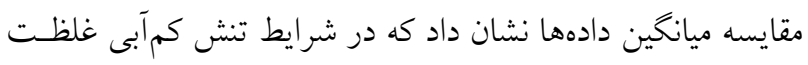
كلروفيل a در همه تيمارها كـاهش يافـت و كمتــرين و بيشترين

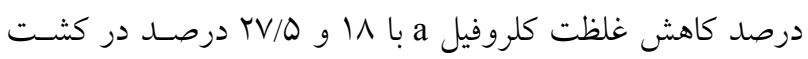

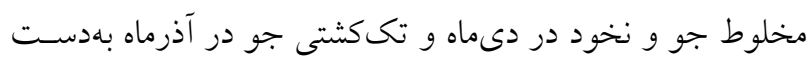

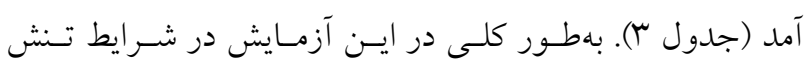

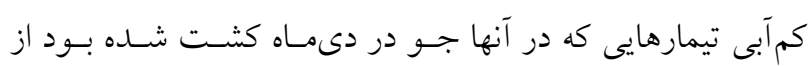

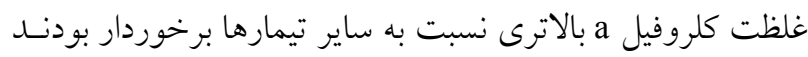

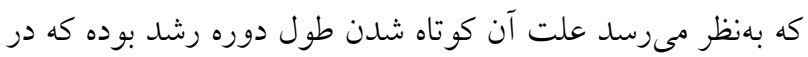

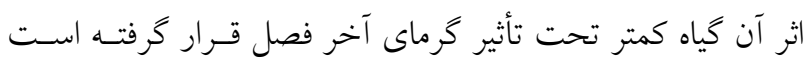

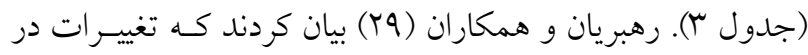

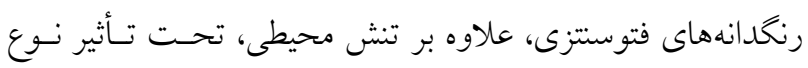

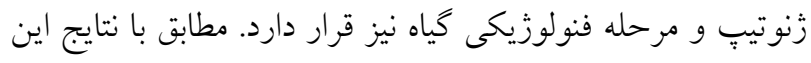

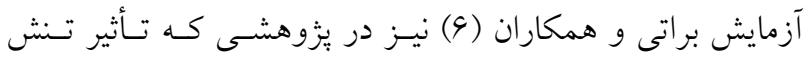

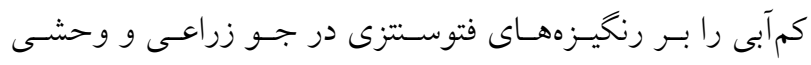

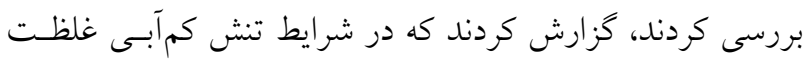

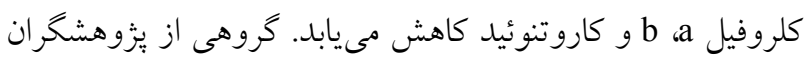




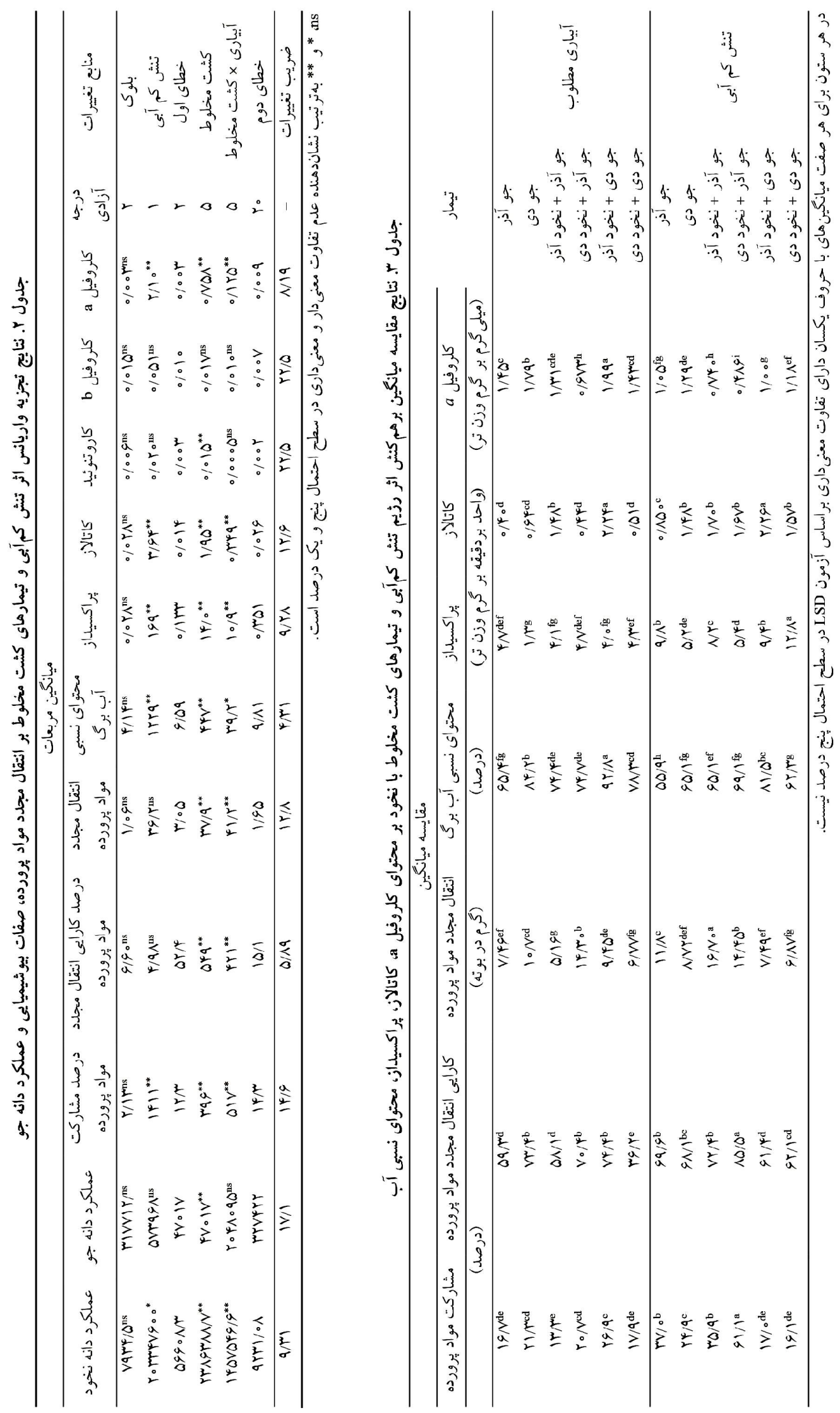




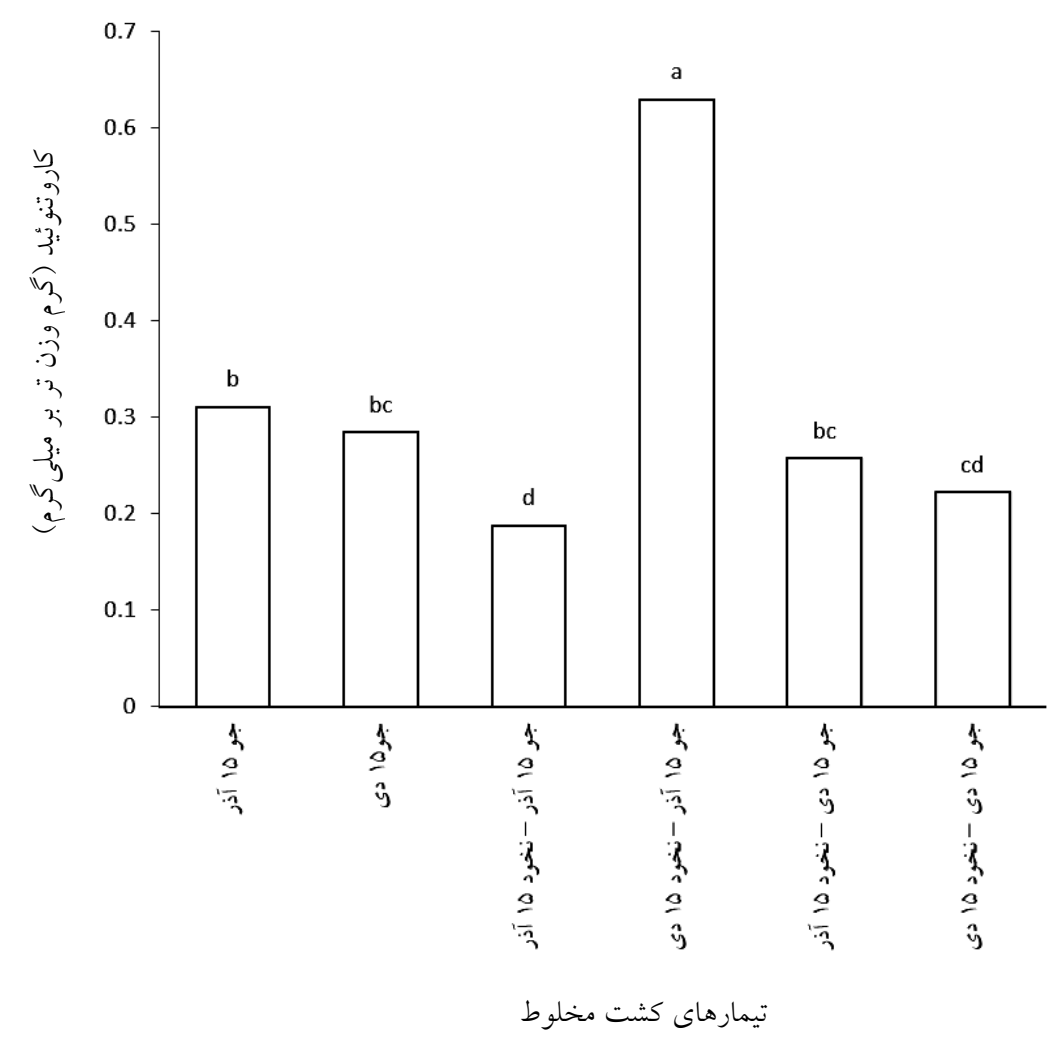

شكل ا. اثر تيمار كشت مخلوط با نخود بر محتواى كاروتنوئيد جو تيمارهاى كشت مخلوط. ميانكينهاى با حروف يكسان داراى تفاوت

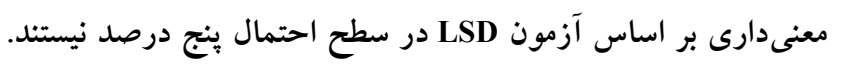

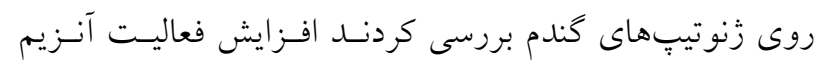

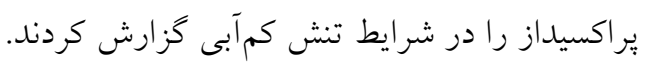

$$
\text { محتواى نسبى آب برى }
$$

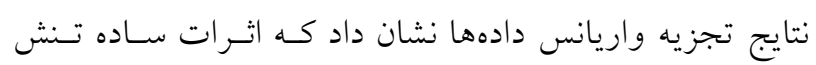

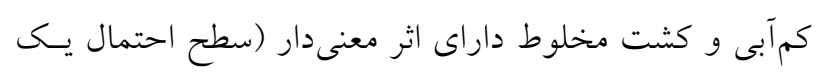

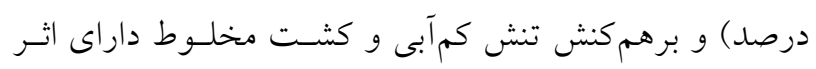

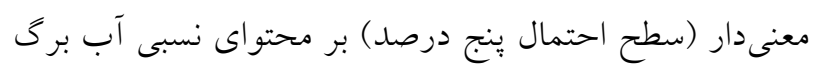

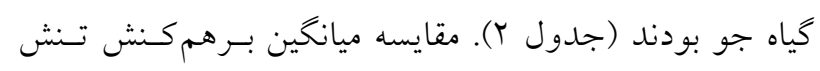

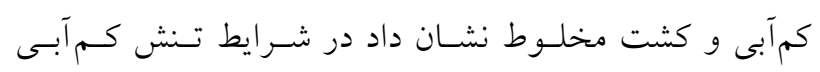

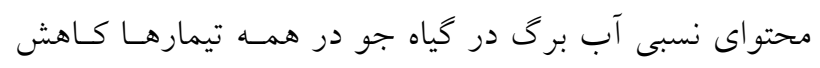

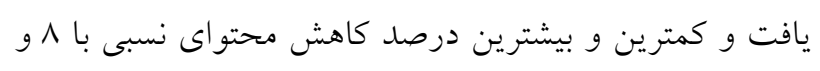

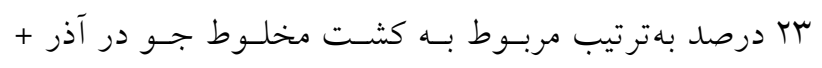

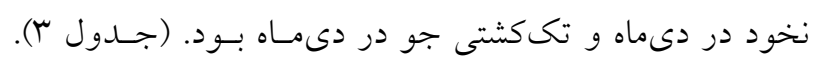

هم:جنين مطابق با نتايج اين آزمايش ردى و كاباله (YN) افـزايش

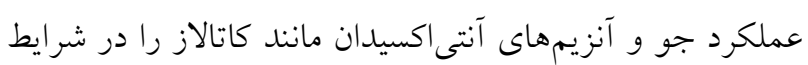
تنش كمآبى خزارش كردند.

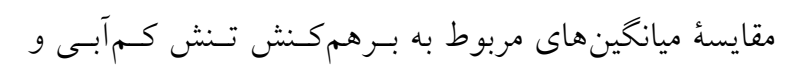

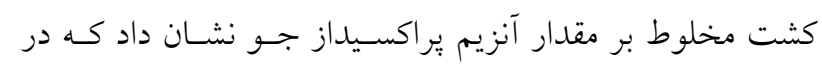

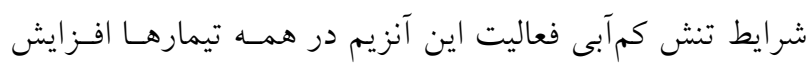

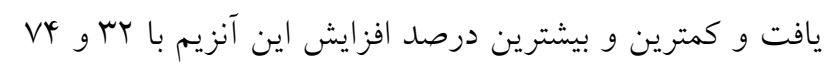

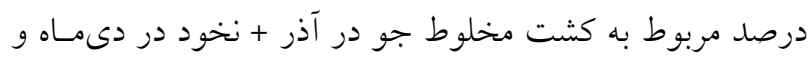

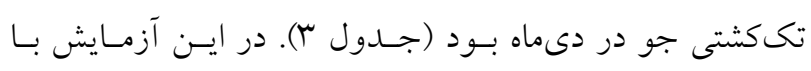

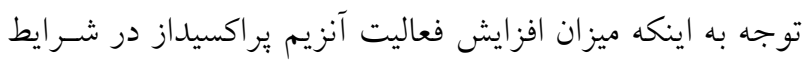

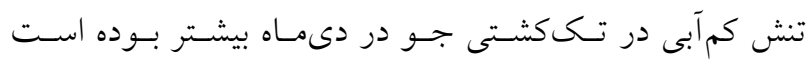

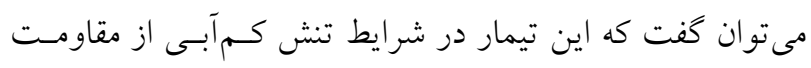

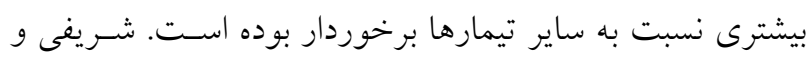

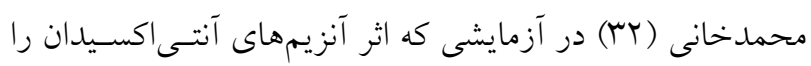


آبيارى و كشت مخلوط داراى اثر معنىدارى در سطح احتمـال يك درصد بر درصد مشاركت مواد يرورده بودنــ (جــدول r) كه كمترين و بيشترين ميـزان افـزايش ايسن صـفت در شـرايط تنش كمآبى با IV و 190 درصد به برتيب در تكى كشتى جو در دىماه و كشت مخلوط جو در آذر + نخود در دىماه بهدسـت

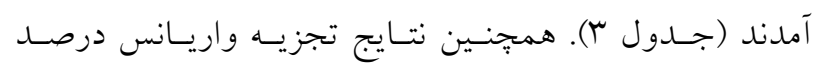

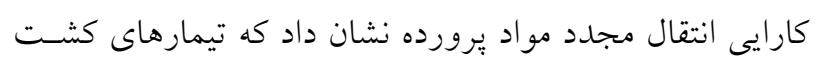

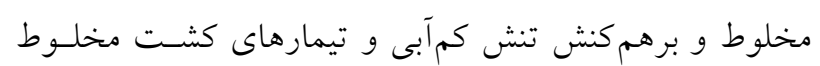
داراى اثر معنىدارى در سطح احتمال يك درصد بر اين صفت بودند ولى اثر ساده تنش كمآبى براى اين صفت معنى دار نبود. (جدول Y). در شرايط تنش كمآبى، كمترين و بيشترين درصد

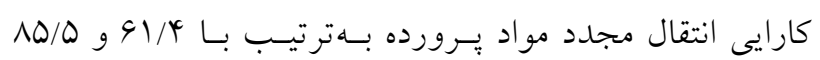
درصد در تيمار جو دى + نخــود آذر و جـو آذر + نخـود دى

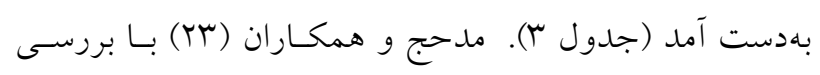
زنوتيبه هاى كنــدم در دو تـاريخ كاشـت مناسـب و تـأخيرى، افزايش با ب درصدى كارايى انتقـال مجـدد مـاده خشـى را در شرايط كرماى انتهاى فصل نسـبت بـه شـرايط بهينـه خـزارش كردند و سهم ذخائر ساقه در رشد دانه نيز در شـرايط كرمـاى انتهاى فصل در همه زنوتيڤها افزايش يافت، ولى اين افزايش در زنوتيٍٍ هاى ديررس بيشتر بود. عزت احمـدى و همكـاران (ه) افزايش بس دروصدى كارايى انتقال مجدد ذخـائر سـاقه و فرايندى مهم و يشتيبانى كننده عملكرد در شرايط تنش كمآبى اعلام كردند كه در يززوهش حاضر اين افزايش OV درصد بود.

\section{عملكرد دانه جو}

عملكرد دانه جو بهطور معنى دارى تحت تـأثير تيمارهـاى كشـت

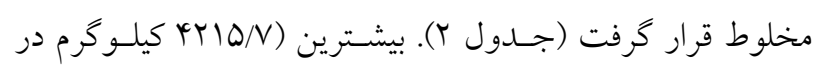

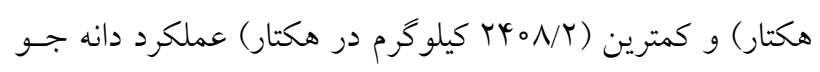
بهترتيب در كشتهاى مخلوط جـو در آذر + نخــود در دىمـاه و جو در دى + نخود در آذرماه بـهدسـت آمــ (شـكل r). در ايسن آزمايش بهنظر مىرسد كه كشـت جـو در تـاريخ كاشـت آذرمـاه

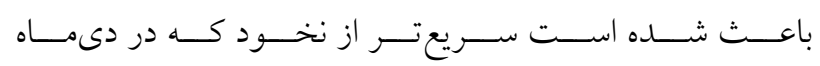

نتايج يزوهشهاى بيشين نشان داد كه در شرايط تنش كم آبسى انتهاى فصل محتـواى نسـبى آب بـرى در كيـاه جـو كـاهش

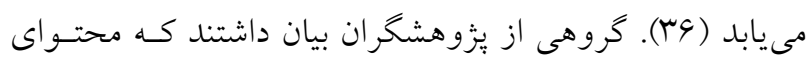

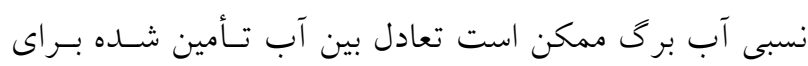

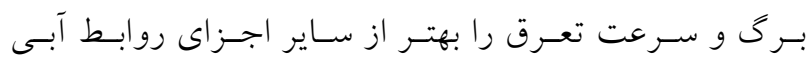
مـنعكس كنـد، لـذا آن را شـاخص مناسـبى بـراى نشـان دادن وضعيت آبى برگ دانستند (Y). كاكالوند و همكاران (Yo) در بررسى كشت مخلـوط سـياهدانه و شـنبليله در شـرايط تـنش كم آبى اظهار كردند كه بيشترين محتواى نسبى آب برى بـ بـراى

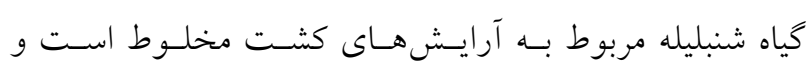
بهورو معنى دارى از كشـت خـالص بيشـتر بـود و بــراى گيـاه

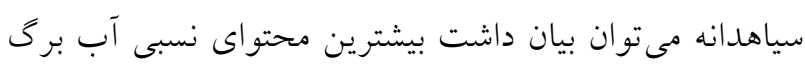

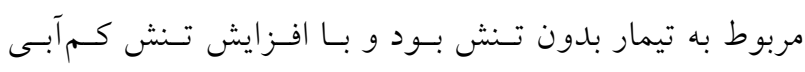

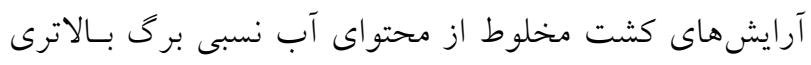

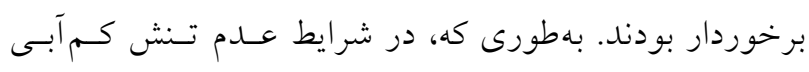
بيشـترين محتــواى آب نســبى بــرى در تيمارهــاى شــبليله:

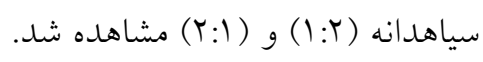

ميزان انتقال مجدد مواد يرورده

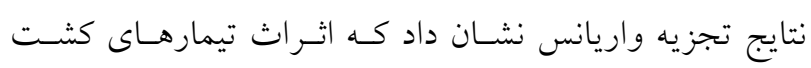
مخلوط و برهم كنش تنش كمآبى و كشـت مخلـوط دار اي اثـر معنى دارى (سطح احتمال يك درصد) بر ميـزان انتقـال مجــد ميد

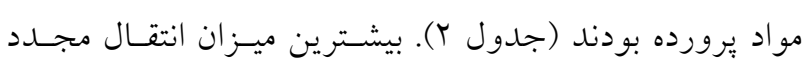
مواد يرورده در تيمار جو در آذر + نخود در آذرماه در شـرايط تنش كمآبى بهدست آمد كه با ساير تيمارها اختلاف معنىدارى

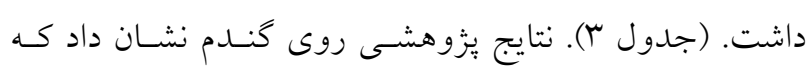

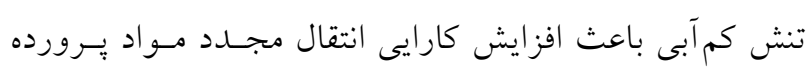

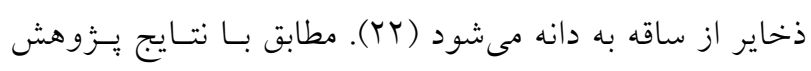

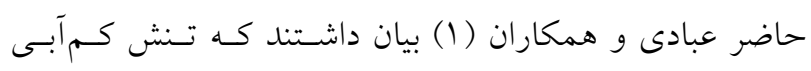

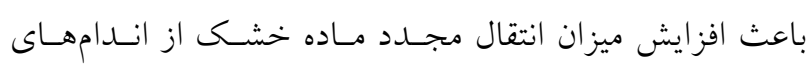

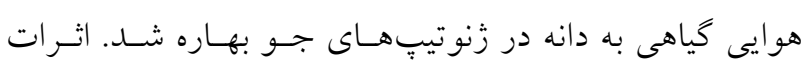
ساده رزيم آبيارى، تيمارهاى كشت مخلوط و برهم كنش رذبي دريم 


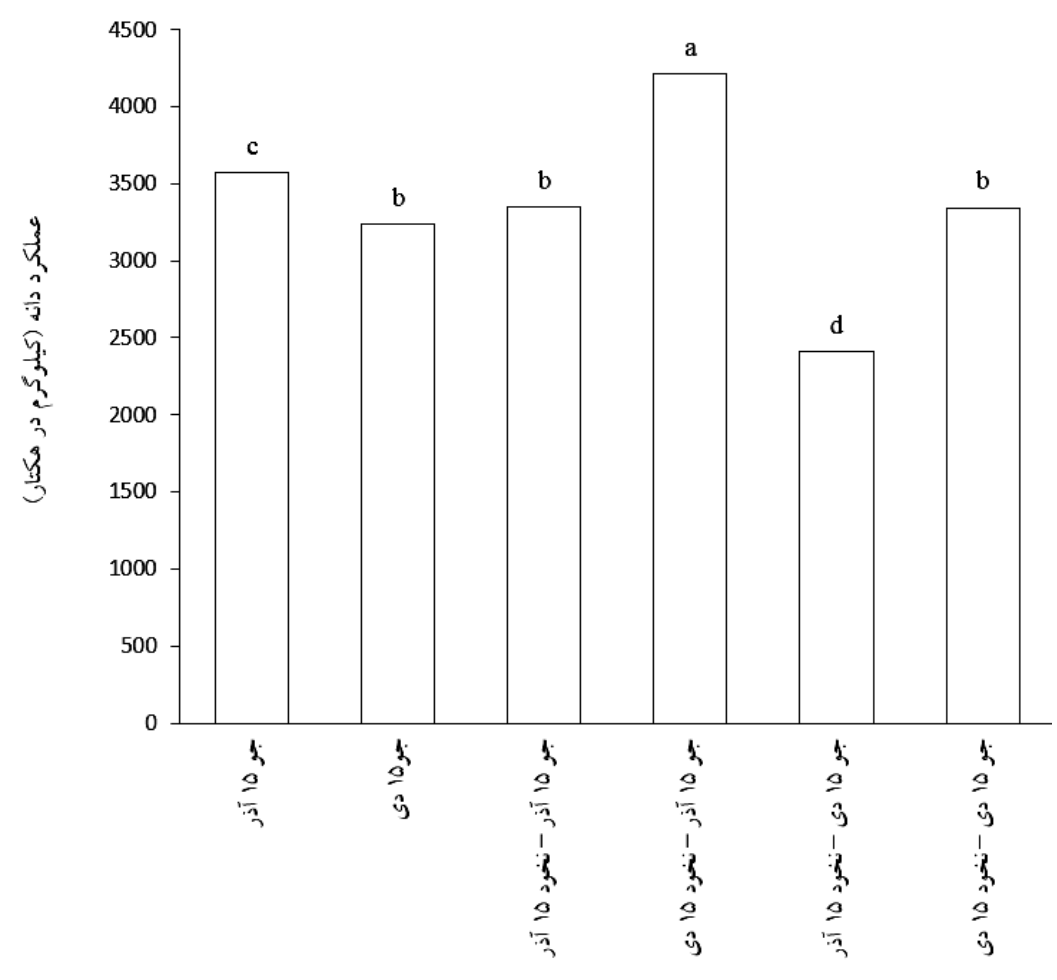

تيمارهاى كشت خالص جو و كشت مخلوط

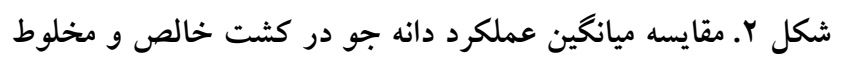

(ميانگينهاى داراى حروف مشترك در هر تيمار بر اساس آزمون LSD در سطح احتمال ينج درصد، تفاوت معنى دارى ندان ندارند).

عملكرد دانه نخود تجزيه واريانس عملكرد دانه نخود نشان داد كه تنش كم آبى اثـر

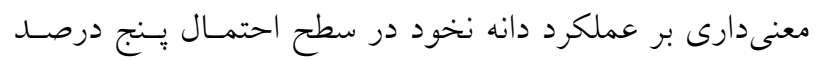

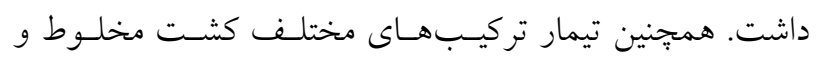

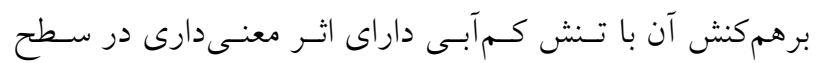

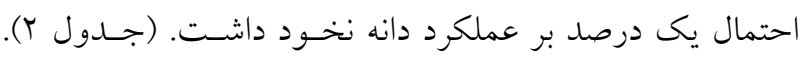

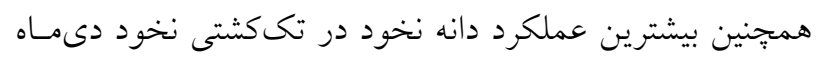

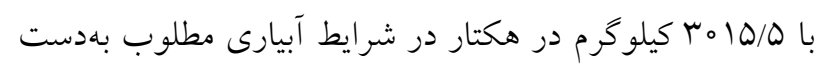

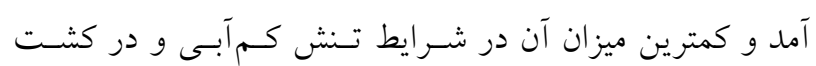

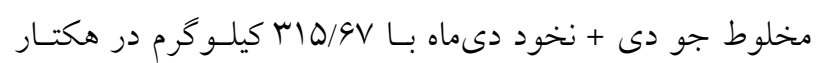

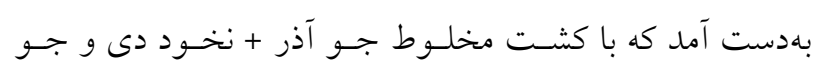

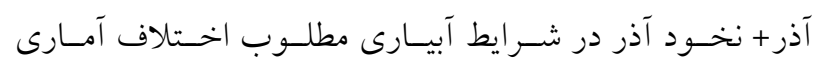

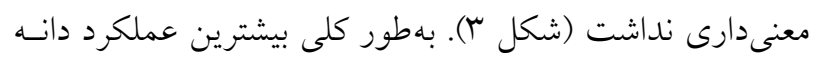

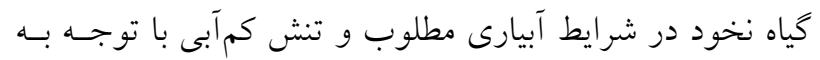
ى

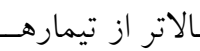
ب

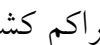

كشت شده است رشد كرده و وارد مرحله رشد رويشى و زايشى شود و كياه غالب بوده و نخود دىماه رقابت كمترى با جو ايجـاد

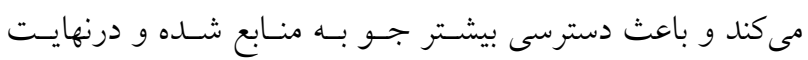

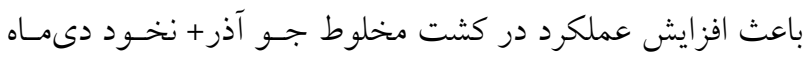

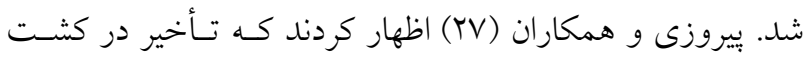

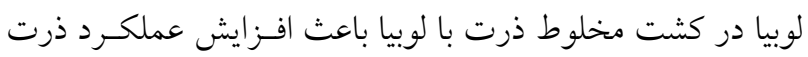

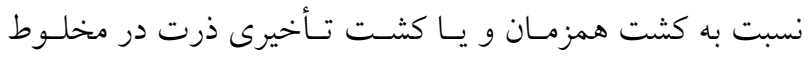
ذرت با لوبيا شد. هس و همكـاران (IV) در بررسى خـود نشـان

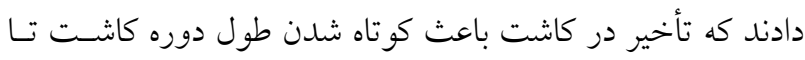
كلدهى و رسيدگى مىشود بهطورى كه كاهش عملكـرد ناشسى از

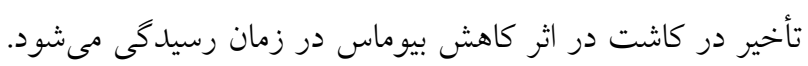
از دلايل كاهش عملكرد در كشت مخلوط جو دى + نخود آذرماه

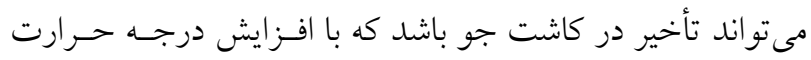
در طى دوره كلدهى موجب كاهش طـول رسـيدكى، وزن دانسه و درنهايت كاهش عملكرد شد. 


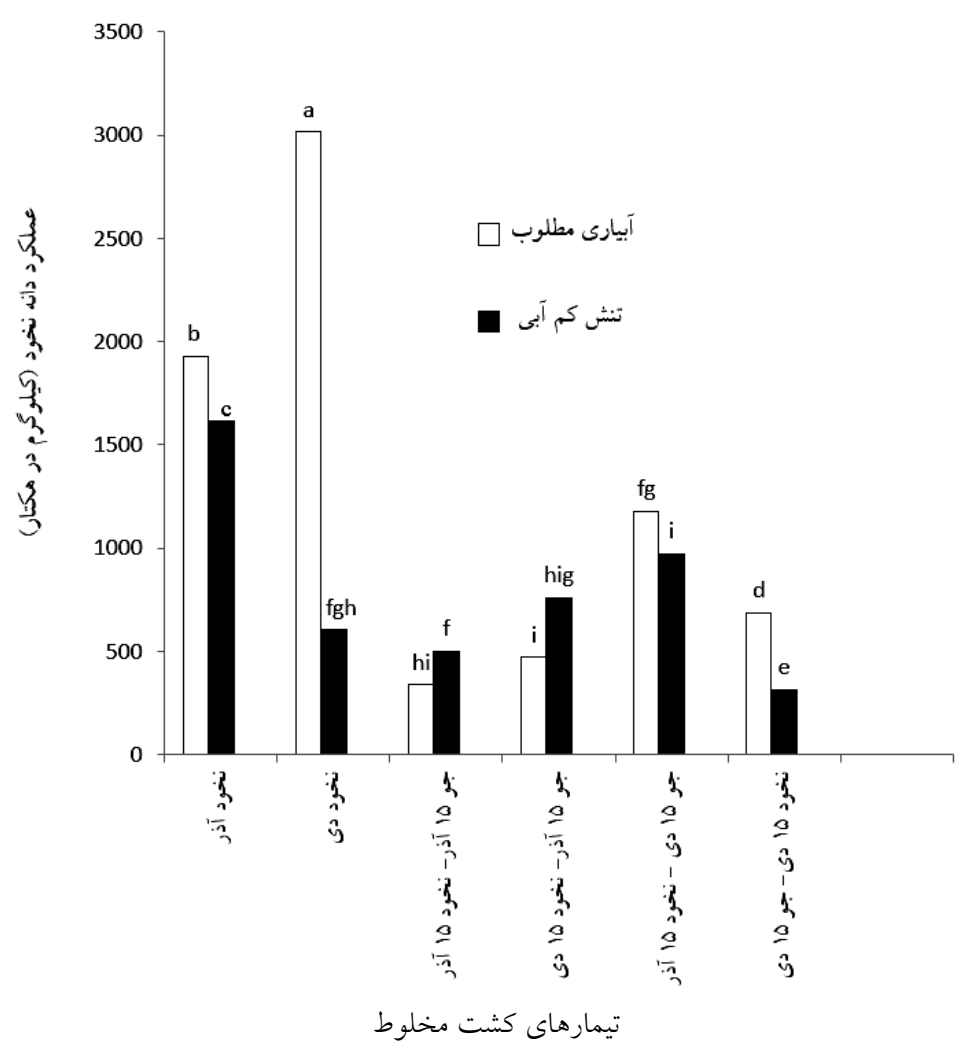

شكل r. برهم كنش تيمارهاى آبيارى و كشت مخلوط بر عملكرد دانه نخود

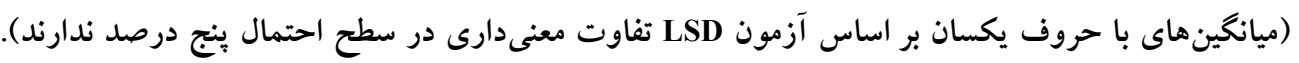

معنى دارى داشت. نتايج همبستخى در شرايط تنش كـمـآبس نشـان

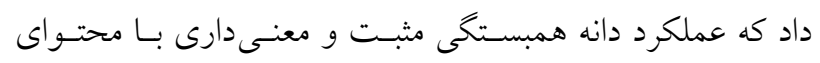

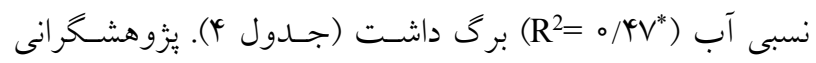

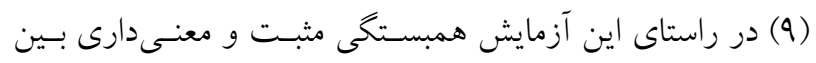

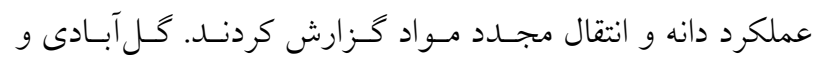

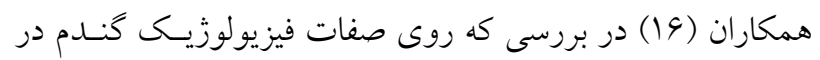

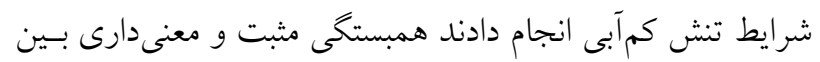

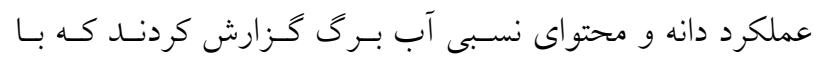

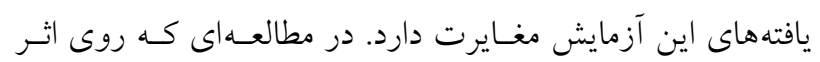

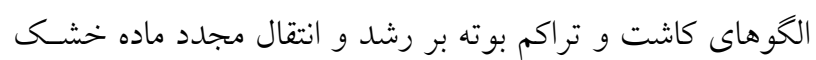

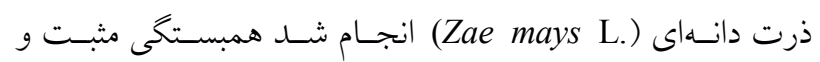
معنى دارى با عملكرد دانه ذرت گزارش كرد (سب). مطابق با نتسايج aزوهش حاضر (YI) همبستخى مثبت و معنى دارى بـا كلروفيـل

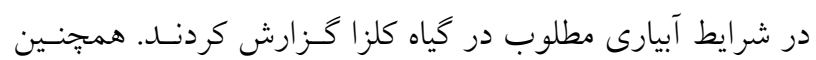

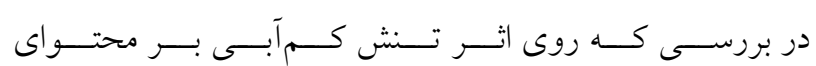

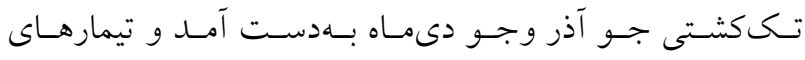
تكى كشتى نسبت به كشت مخلوط برترى داشـتند؛ كـه بـا نتـايج

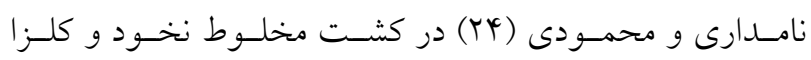

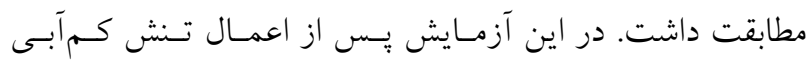

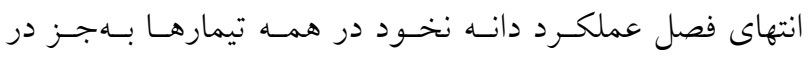

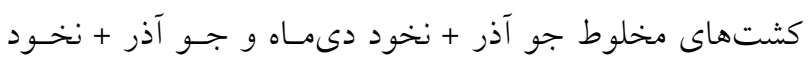

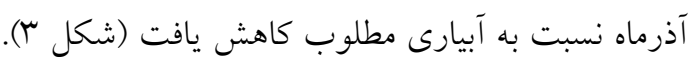

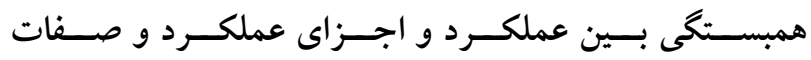
فيزيولوزيك گياه جو در شرايط آبيارى مطلوب و تنش كمآبى نتايج همبستخى در شرايط آبيارى مطلوب نشان داد كـه عملكـرد دانه با محتواى كلروفيل a (

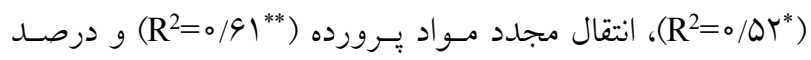

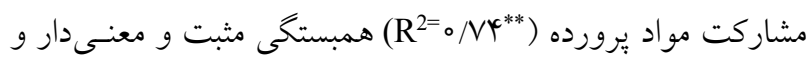
بـا فعاليـت آنـزيم كاتـالاز (R 


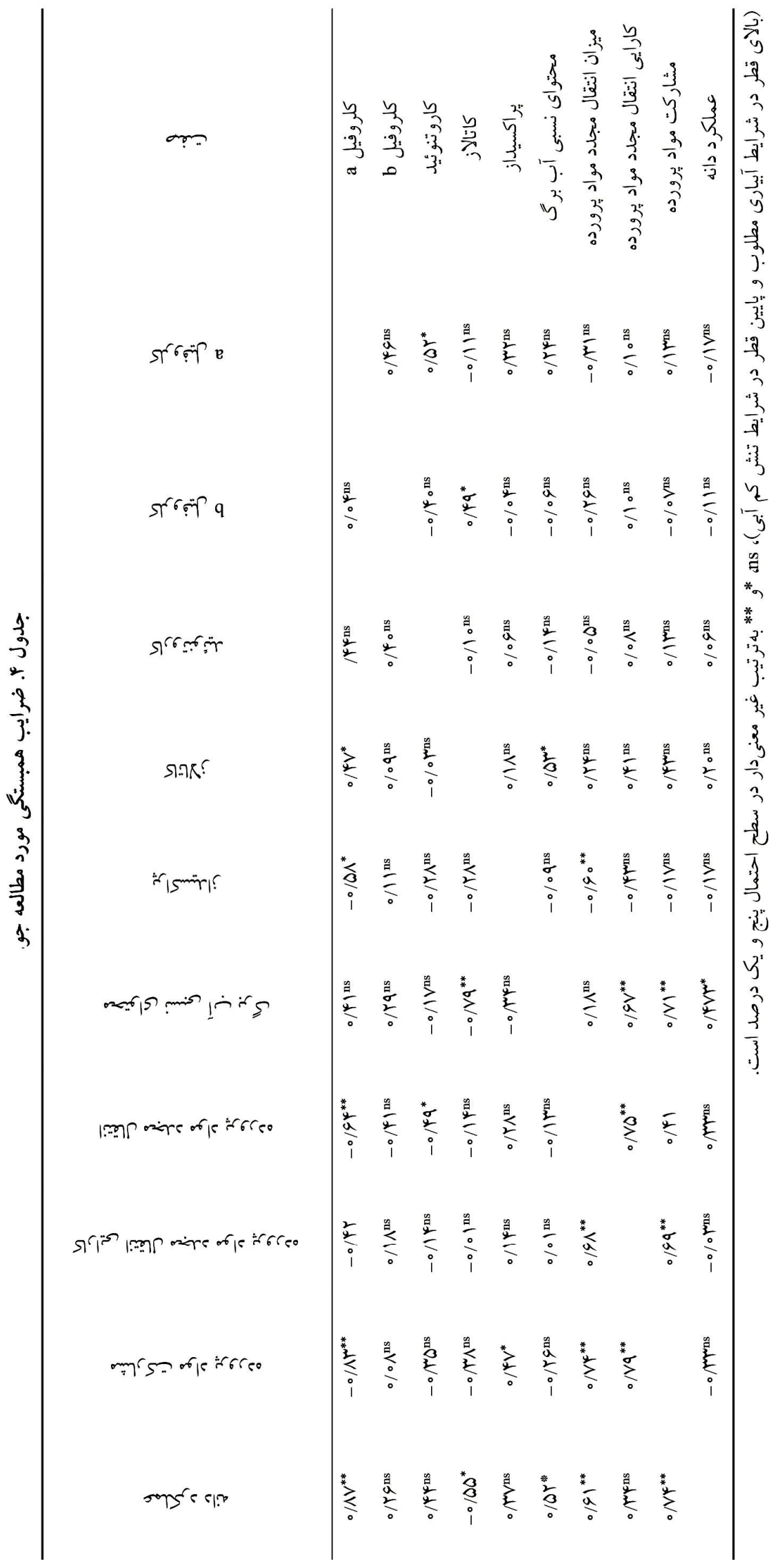




$$
\begin{aligned}
& \text { بيشترين ميزان انتقال مجدد مـواد يــرورده را بـهدسـت آورد. در } \\
& \text { مجموع مىتوان جنين بيان كرد كه كه مقدار ماده خشـك توليـد } \\
& \text { شده عامل مهمى در انتقال مجلدد مـاده خشـك بـه دانـه اسـت. } \\
& \text { همجنين نتايج نشان داد كه در شـرايط تــش كــمآبـى محتـواى } \\
& \text { كلروفيـل a و محتــواى نسـبى آب بـرى جـــ كـاهش يافـت و } \\
& \text { بيشترين ميزان محتواى كاروتنوئيد و آنزيم كاتالاز جو در كشت } \\
& \text { مخلوط جو در آذر + نخود در دىماه بهدست آمد. }
\end{aligned}
$$$$
\text { نسبى آبى برگ و شاخص كلروفيل در لوبيـا جيتى انجـام شـد }
$$

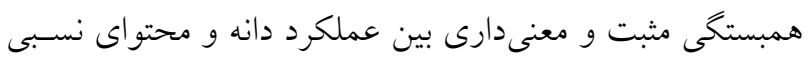$$
\text { آب برگ گزارش كردند (سم). }
$$

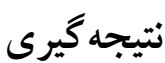

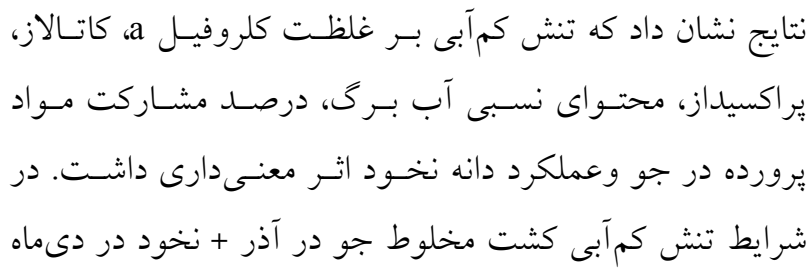

منابع مورد استفاده

1. Abedi Baba Arabi, S., M. Movahhedi Dehnavi, A. R. Yadavi and E. Adhami. 2011. Effects of Zn and K foliar application on physiological traits and yield of spring safflower under drought stress. Electronic Journal of Crop Production 4(1): 75-95. (In Farsi).

2. Aebi, H. 1984. Catalase in vitro. Methods in Enzymology 105: 121-126.

3. Ahmed, I. M., H. Dai, W. Zheng, F. Cao, G. Zhang, D. Sun and F. Wu. 2013. Genotypic differences in physiological characteristics in the tolerance to drought and salinity combined stress between Tibetan wild and cultivated barley. Plant Physiology and Biochemistry 63: 49-60.

4. Arnon, A. N. 1967. Method of extraction of chlorophyll in the plants. Journal of Agronomy 23: 112-121.

5. Bahrani, A. 2011. Remobilization of dry matter in wheat: effects of nitrogen application and post-anthesis water deficit during grain filling. International Conference on Biology Environment and Chemistry 5: 155-160. (In Farsi).

6. Barati, M., M. M. Majidi, M. Safari, A. Mirlohi and K. H. Zeinalinejad. 2017. Evaluation of drought tolerance indices and physiological traits in cultivated and wild barley. Journal of Crop Production and Processing 7(2): 118. (In Farsi).

7. Barrsu, H. D. and P. E. Weatherley. 1962. Are-examination of the relative turgidity technique for estimating water deficits in leaves. Australian Journal Biological Sciences 15: 413-428.

8. Bedoussac, L., E. P. Journet, H. Hauggaard-Nielsen, C. Naudin, G. Corre-Hellou, E. S. Jensen, L. Prieur and E. Justes. 2015. Ecological principles underlying the increase of productivity achieved by cereal-grain legume intercrops in organic farming. A review. Journal of Agronomy for Sustainable Development 35(3): 911-935.

9. Beheshti, A. and B. Behbodifard. 2010. Dry matter accumulation and remobilization in grain sorghum genotypes (Sorghum bicolor L.) under normal and low water stress conditions. Iranian Journal of Field Crops Research 8(4): 717-725. (In Farsi)

10. De La Fuente, E. B., S. A. Suarez, A. E. Lenardis and S. L. Poggio. 2014. Intercropping sunflower and soybean in intensive farming systems: evaluating yield advantage and effect on weed and insect assemblages. NJASWageningen Journal of Life Science 70: 47-52.

11. Duchene, O., J. F. Vian and F. Celette. 2017. Intercropping with legume for agroecological cropping systems: complementarity and facilitation processes and the importance of soil microorganisms. A review. Journal of Agriculture Ecosystems Environment 240: 148-161.

12. Ebadi, A., K. Sahed and A. H. Sanjari. 2011. The effect of irrigation cut on dry matter remobilization and some of agronomy traits on spring barley. Electronic Journal of Crop Production 4(4): 19-37. (In Farsi).

13. Emam, Y. 2018. Crop Physiology. Iran: Tehran, Iranian University Press. (In Farsi).

14. Ercolia, L., L. Lullib, M. Mariottib, A. Masonib and I. Arduinib. 2008. Post-anthesis dry matter and nitrogen dynamics in durum wheat as affected by nitrogen supply and soil water availability. European Journal of Agronomy 25: 138-147.

15. Ezzat Ahmadi, M., G. H. Noormohammadi, M. Ghodsi and M. Kafi. 2009. Effects of water deficit and spraying of desiccant on yield components and water use efficiency of wheat genotypes. Pakistan Journal Biological Science 12: 1399-14707.

16. Golabadi, M., Z. Abbasi and A. R. Golparvar. 2014. Variations in physiological indices of bread wheat flag leaf in 
response to drought stress. Journal of Environmental Stress in Crop Sciences 7(1): 1-11. (In Farsi).

17. He, D., E. Wang, J. Wang, J. Lilley, Z. Luo, X. Pan and N. Yang. 2017. Uncertainty in canola phenology modelling induced by cultivar parameterization and its impact on simulated yield. Agricultural and Forest Meteorology 232: 163-175.

18. Homayoun, H. 2011. Remobilization of stem reserves in wheat varieties under normal and drought stress conditions. Advances in Environmental Biology 5: 1721-1724.

19. Hui-Ping, D., Sh. Chan-juan, W. An-Zhi and Y. Tuxi. 2012. Leaf senescence and photosynthesis in foxtail (Setaria italica L) varieties exposed to drought conditions. Australian Journal of Crop Science 6(2): 232-237.

20. Kakulvand, R., S. Fallah and A. Abassi Soyrki. 2017. Effects of species competition on photosynthetic pigments, prolin relative water content, and essence fenugreek (Trigonella foenum graceum) and black cumin (Nigella sativa L.) under drought stress conditions in intercropping system. Journal of Plant Process and Function 6(19): 255-269. (In Farsi).

21. Kalantar Ahmadi, S. A., A. Ebadi, J. Daneshian, S. A. Siadat and S. Jahanbakhsh. 2017. Effect of drought stress and foliar application of growth regulators on photosynthetic pigments and seed yield of rapeseed (Brassica napus L. cv. Hyola 401). Iranian Journal of Crop Sciences 18(3): 196-217. (In Farsi).

22. Ma, J., G. B. Huang, D. L. Yang and Q. Chai. 2013. Dry matter remobilization and compensatory effects in various internodes of spring wheat under low water stress. Journal of Crop Science 54: 331-339.

23. Modhej, A., Y. Emam and A. Ayenehband. 2011. Effect of nitrogen levels on source restriction and the pattern of assimilate redistribution to grains in wheat genotypes under post-anthesis heat stress conditions. Iranian Journal of Field Crops Research 9(3): 474-485. (In Farsi).

24. Namdari, M. and S. Mohmoodi. 2013. Evaluation of yield and productivity indices in planting ratios of intercropping of chickpea (Cicer arietinum L.) and canola (Brassica napus L.). Iranian Journal of Crop Science 14(4): 346-357. (In Farsi).

25. Netanos, D. A. and S. D. Koutroubas. 2012. Dry matter and N accumulation and translocation For Indica and Japonica rice under Mediterranean conditions. Field Crops Research 74: 93-101.

26. Omidi, H., F. Movahadi and Sh. Movahadi. 2012. The effect of salicylic acid and scarification on germination characteristics and proline, protein and soluble carbohydrate content of Prosopis (Prosopis farcta L.) seedling under salt stress. Range and Desert Research 18(4): 608-623.

27. Piroozi, B., S. M. B. Hosseini, D. Mazaheri and H. Heidari. 2012. Evaluation of sowing time and intercropping on vegetative and reproductive traits of bean (Phaseolus vulgaris) and biological yield of forage maize (Zea mays). Agronomy Journal (Pajouhesh and Sazandegi) 104: 62-68. (In Farsi).

28. Rady, M. M. and M. S. Gaballah. 2012. Improving barley yield grown under low water stress conditions. Research Journal of Recent Sciences 1: 1-6.

29. Rahbarian, R., R. Khavari-Nejad, A. Ganjeali, A. R. Bagheri and F. Najafi. 2011. Drought stress effects on photosynthesis, chlorophyll fluorescence and water. Acta Biological cracoviensia Series Botanica 53(1): 47-56. (In Farsi).

30. Sanchez-Rodriguez, E., M. Rubio-Wilhelmi, L. M. Cervilla, J. J. Blasco, Brios, M. A. Rosales, L. Romero and J. M. Ruiz. 2010. Genotypic differences in some physiological parameters symptomatic for oxidative stress under moderate drought in tomato plants. Journal of Plant Science 178: 30-40.

31. Schlemmer, M. R., D. D. Francis, J. F. Shanahan and J. S. Schepers. 2005. Remotely measuring chlorophyll content in corn leaves with differing nitrogen levels and relative water content. Journal of Agronomy 97: 106-112.

32. Sharifi, P. and N. Mohammad Khani. 2016. Physiological responses and activity of antioxidant enzymes of different wheat genotypes under drought stress. Journal of Applied Research of plant Ecophysiology 3(2): 103-126.

33. Soheili Movahhed, S., M. Esmaeili, F. Jabbari, S. Khorramdel and A. Fouladi. 2017. Effects of water deficit on relative water content, chlorophyll fluorescence indices and seed yield in four pinto bean genotypes. Journal of Crop Production 10(1): 169-190. (In Farsi).

34. Sorkhy, F. 2016. Effect of planting pattern and dry matter remobilization and grain yield of maize (Zae mays L.). Journal of Crop Physiology 9(34): 61-78.

35. Stoltz, E., E. Nadeau and A. Wallenhanmar. 2013. Intercropping Maize and faba bean for silage under swedish climate conditions. Journal of Agriculture Research 2(1): 90-97.

36. Vaezi, B., V. Bavei and B. Shiran. 2010. Screening of barley genotypes for drought tolerance by agro-physiological traits in field condition. African Journal of Agricultural Research 5: 881-892. (In Farsi).

37. Wang, L. J., L. Fan, W. Loescher, W. Duan, G. J. Liu, J. S. Cheng, H. B. Luo and S. H. Li. 2010. Salicylic acid alleviates decreases in photosynthesis under heat stress and accelerates recovery in grapevine leaves. Journal of BMC Plant Biological 10: 34-48.

38. Yang, C., G. Huang, Q. Chai and Z. Luo. 2011 Water use and yield of wheat/maize intercropping under alternate irrigation in the oasis field of northwest China. Journal of Field Crops Research 124: 426432.

39. Zadokes, J. C., T. T. Chang and C. F. Konzak. 1974. A decimal code for the growth stages of cereals. Journal of Weed Research 14: 415-421. 


\title{
Evaluation of Biochemical Traits and Dry Matter Remobilization of Barley (Hordeum vulgare L.) in Relay Intercropping with Chickpea (Cicer arietinum L.) under Deficit Water Stress Conditions
}

\author{
N. Mohavieh Asadi ${ }^{1}$ and E. Bijanzadeh ${ }^{*}$
}

(Received: May 4-2020; Accepted: November 25-2020)

\begin{abstract}
In order to investigate the effect of deficit water stress and different combinations of relay intercropping of chickpea with barley on some biochemical traits and grain yield, a field experiment was conducted at College of Agriculture and Natural Resources of Darab, Shiraz University during 2017-2018 cropping season, as split plot based on a randomized complete block design with three replications. Treatments included two irrigation regimes (normal irrigation and cutting off irrigation at milk development stage) as main factor and the 6 combinations of cropping systems consisted of cultivation of barley on December, barley on January, and different combinations of intercropping consisted of barley in December + chickpea in December, barley in December + chickpea in January, barley in January + chickpea in December, and barley in January + chickpea in January with a ratio of 1:1 as sub factor. Results showed that deficit water stress had significant effects on chlorophyll $a$, catalase and peroxidase activity, leaf relative water content (RWC) and contribution of current photoassimilates to the grain yield of barley and grain yield of chickpea. Under deficit water stress, barley grain yield had a positive correlation with leaf relative water content $\left(\mathrm{R}^{2}=0.4\right)^{*}$. Also, under deficit water stress condition, the highest carotenoid content was obtained from intercropping of barley in December + chickpea in January. Since intercropping of barley in December + chickpea in January had the highest carotenoid content, remobilization efficiency, and contribution of current photoassimilates to the grain yield of barley and hence grain yield of barley $(4215.7 \mathrm{~kg} / \mathrm{ha})$, it may be a suitable cultural strategy to be taken under late season deficit water stress conditions.
\end{abstract}

Keywords: Catalase, Carotenoid, Chlorophylla, Peroxidase, Relative Water content

1,2. M.Sc. Student and Associate Professor, Respectively, Agroecology Department, College of Agriculture and Natural Resources of Darab, Shiraz University, Darab, Iran

*: Corresponding Author, Email: bijanzd@shirazu.ac.ir 